\title{
Microzooplankton grazing in the Estuary of Mundaka, Spain, and its impact on phytoplankton distribution along the salinity gradient
}

\author{
A. Ruiz, J. Franco, F. Villate* \\ Laboratorio de Ecología, Departamento de Biología Vegetal y Ecología, Facultad de Ciencias, Universidad del País Vasco, \\ Apdo 644, E-48080 Bilbao, Spain
}

\begin{abstract}
Microzooplankton grazing impact $(<200 \mu \mathrm{m}$ fraction) on phytoplankton along a salinity gradient in the Estuary of Mundaka (Bay of Biscay, Spain) was analyzed during summer (August 1990) using a serial dilution method. Both microzooplankton grazing rate and phytoplankton growth rate were high (mean $g=0.75 \mathrm{~d}^{-1}$, mean $k=1.90 \mathrm{~d}^{-1}$ respectively), and well correlated denoting an optimization in the efficiency of energy transport through the pelagic food web. Microzooplankton herbivory represented a mean loss of $38 \%$ of initial standing stock of chlorophyll and $46 \%$ of potential phytoplankton primary production in the inner zone of the estuary, where changes in phytoplankton biomass were mainly a function of initial hiomass. In the intermediate and outer zones, microzooplankton grazed around $54 \%$ of initial standing stock of chlorophyll and more than $60 \%$ of potential phytoplankton primary production. In these zones, changes in phytoplankton biomass were mainly a function of phytoplankton growth. In spite of the importance of microzooplankton grazing, this factor alone cannot be responsible for the observed phytoplankton distribution along the salinity gradient.
\end{abstract}

KEY WORDS: Microzooplankton grazing · Herbivory impact · Phytoplankton distribution · Estuaries

\section{INTRODUCTION}

Estuaries are one of the most productive systems on Earth, but the fate of this high production remains to be determined. A major question is how much of the primary productivity of estuaries is channelled through the herbivorous trophic chain and how much is utilized by the detritus-decomposer system. In pelagic communities, exploitation of phytoplankton by microzooplankton has been less studied. Nevertheless, studies which have evaluated microzooplankton grazing impact on phytoplankton have suggested that by consuming high percentages of the phytoplankton net productivity microzooplankton are a key trophic constituent in pelagic food webs (e.g. Gallegos 1989, McManus \& EderingtonCantrell 1992). In addition, when comparative analyses on herbivory of meso- and microzooplankton have been carried out in the ocean (Marra et al. 1987. Tsuda et al.

•Addressee for correspondence. E-mail: gvpvigul@lg.ehu.es
1989), the microzooplankton assemblage has been identified as the main consumer of phytoplankton.

In the Estuary of Mundaka (Bay of Biscay, Spain; also called the Gernika or Urdaibai Estuary in the literature), the spatial and temporal distributions of planktonic populations reflect the geomorphological characteristics of this system, which include a low drainage basin:estuary areal ratio (around 70) and tidal prism: mean volume ratios higher than 1 (Villate et al. 1989). The small volume of resident mixohaline waters limits the buffering of salinity changes and, as a consequence, the maintenance of suitable conditions for the development of estuarine populations. Optimal growth and persistence of these populations can only be expected in summer, when freshwater discharges are low and hydrological stability increases within the estuary (Villate 1991, Franco 1994). Nevertheless, in summer, storms can substantially alter the hydrographic regime and plankton dynamics in the estuary, due to the relatively small size of the watershed (Ruiz 1995). 


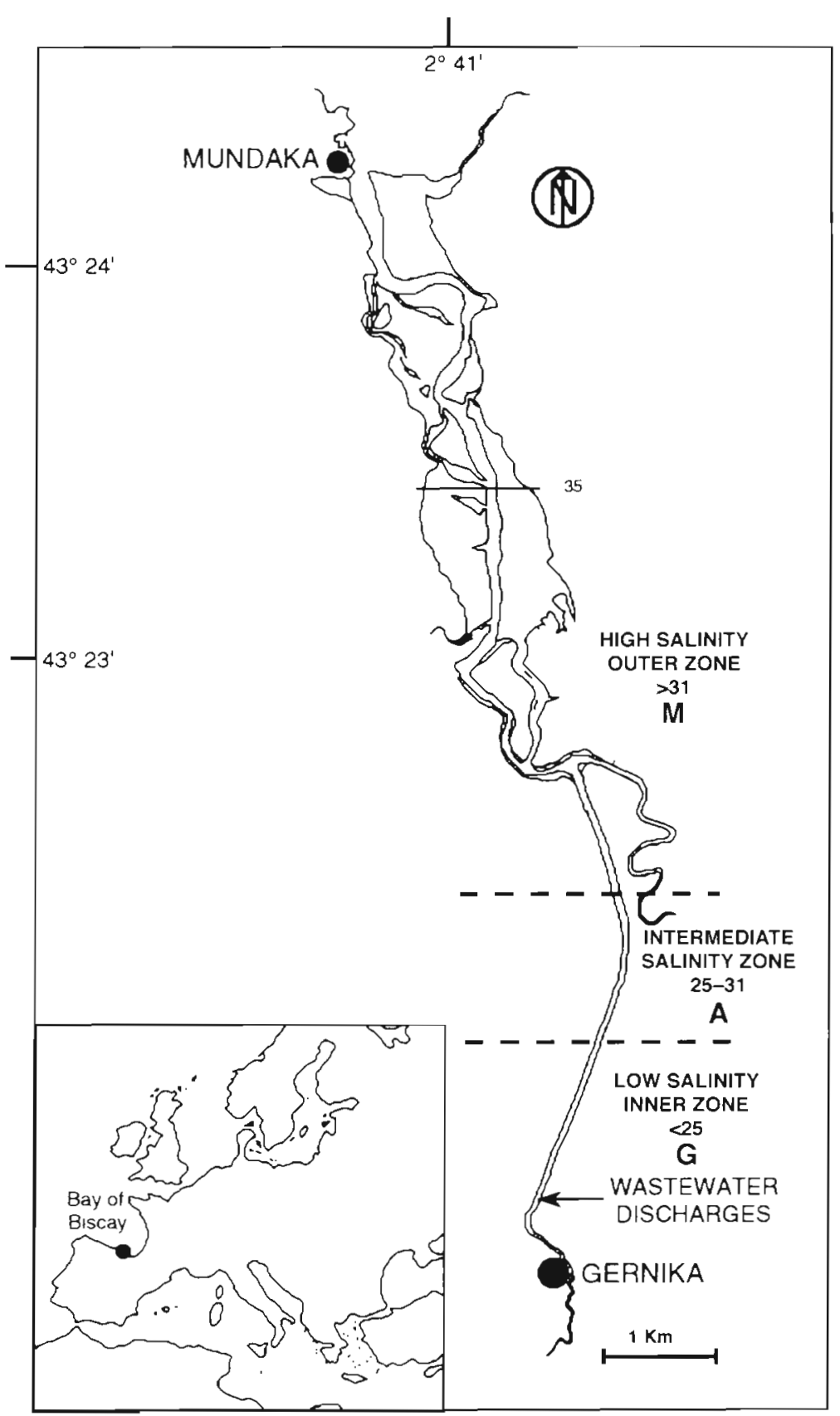

Fig. 1. Study area in the Bay of Biscay (Spain) and the mean location of water masses of different salinity during high tide in August 1990

Kuuppo-Leinikki 1990, Dolan \& Gallegos 1991, McManus \& Ederington-Cantrell 1992, Muller \& Geller 1993), allows them to adapt faster than mesozooplankton to environmental changes. In this way, microzooplankton can better exploit sudden food increases than mesozooplankton and usually show the highest abundance in seasons of maximal production (Smetacek 1981).

The highest phytoplankton production and biomass in the Estuary of Mundaka are found in summer, when high temperature and solar radiation together with the hydrological stability provide a suitable enviromment for algal growth (Franco 1994). Because of the high density of small zooplanktonic forms, coupled to their high metabolic rates, the microzooplankton can potentially be at least as important as mesozooplankton in controlling phytoplankton populations (e.g. Hewes et al. 1985). Thus, microzooplankton grazing could be expected to be significant in estuaries.

The aim of this work was to evaluate the importance of microzooplankton grazing (<200 $\mu \mathrm{m}$ fraction) on phytoplankton distribution along the salinity gradient in the Estuary of Mundaka in summer, the season when biological interactions are supposed to govern the spatial and temporal patterns of phytoplankton dynamics to a greater extent.

\section{MATERIALS AND METHODS}

Field observations. Several cruises were carried out in the Estuary of Mundaka (Fig. 1) during July 1990 to determine the distribution of chlorophyll concentration along the salinity gradient. Results showed the existence of a consistent pattern characterized by a chloro-

The conditions found in such estuaries will influence the growth of large species of zooplankton more than the microbial populations. This is illustrated by the moderate abundance of mesozooplanktonic populations in mesohaline and polyhaline waters and the absence of Eurytemora species (Villate 1991), which is a typically common mesozooplankter in other estuaries (e.g Castel 1993, Peitsch 1993). The short life-cycle of protozooplanktonic species, sometimes with duplication rates higher than $1 \mathrm{~d}^{-1}$ (Rivier et al. 1985, phyll maximum in the inner zone (salinity lower than 25), a relative minimum in the intermediate zone (salinity between 25 and 31 ) and a secondary peak in the outer zone (salinity higher than 31) (Fig. 2A).

Sampling. Taking into account this pattern, which remained in August (Fig. 2B), we designed a sampling program to study the effect of microzooplankton grazing on both the inner and the outer chlorophyll peaks, and on the intermediate minimum. We identified the water masses containing higher and lower chlorophyll 

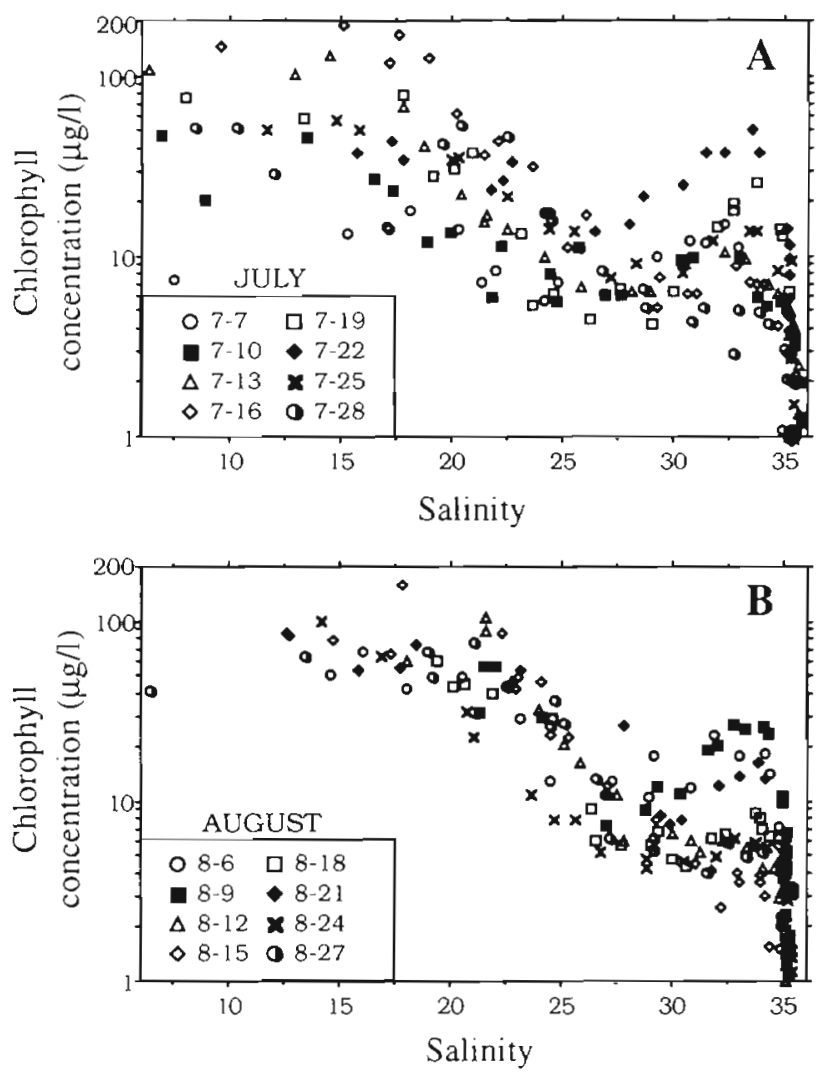

Fig. 2. Chlorophyll concentration along the salinity gradient in July and August 1990. Sampling dates given as month-day

using salinity, because the conservative behavior of salinity allowed the identification of the different water masses and the specific communities along the estuary better than did the use of fixed station locations. Two days after the initial survey, microzooplankton grazing experiments were conducted. The following day a further cruise was undertaken to determine the distribution of chlorophyll in the estuary. This protocol was repeated 7 times from August 6 to 27 .

Experimental procedure. To determine the microzooplankton grazing rate on phytoplankton we employed the dilution method introduced by Landry \& Hassett (1982). Samples were collected from the surface and at $0.5 \mathrm{~m}$ above the bottom by a hand-pump. Water was filtered through $200 \mu \mathrm{m}$ mesh screens to remove meso- and macroplankton. Therefore, measured grazing corresponded really to both microzooplankton (20 to $200 \mu \mathrm{m}$ ) and nanozooplankton (2 to $20 \mu \mathrm{m}$ ); however, we will use the word microzooplankton to refer both fractions. A set of dilutions was prepared with water passed through Whatman GF/C glass-fiber filters. The filtered water was combined with unfiltered water to obtain 21 of water with the following percentages of unfiltered water: $100,87.5,75$, $62.5,50$ and $37.5 \%$. Because of the high values of
Table 1. Mean, standard deviation and minimum values of concentration of inorganic dissolved nutrients in $\mu \mathrm{g}$-at. $\mathrm{I}^{-1}$ for the 3 considered salinity ranges. $N$ : nitrate, nitrite and ammonium; P: reactive phosphorus; Si: silicate

\begin{tabular}{|cccccccc|}
\hline & \multicolumn{4}{c}{$<25$} & \multicolumn{2}{c}{$25-31$} & \multicolumn{2}{c|}{$>31$} \\
& $\begin{array}{c}\text { Mean } \\
(\mathrm{SD})\end{array}$ & $\begin{array}{c}\text { Mini- } \\
\text { mum }\end{array}$ & $\begin{array}{c}\text { Mean } \\
\text { (SD) }\end{array}$ & $\begin{array}{c}\text { Mini- } \\
\text { mum }\end{array}$ & $\begin{array}{c}\text { Mean } \\
\text { (SD) }\end{array}$ & $\begin{array}{c}\text { Mini- } \\
\text { mum }\end{array}$ \\
\hline $\mathrm{N}$ & $261(87.5)$ & 147 & $109(33.3)$ & 59 & $26(13.2)$ & 1.9 \\
$\mathrm{P}$ & $37(14.4)$ & 20 & $11(3.5)$ & 5.6 & $2.9(1.4)$ & 0.9 \\
$\mathrm{Si}$ & $56(25.5)$ & 13 & $33(10.7)$ & 18 & $9.8(6.8)$ & 1.7 \\
\hline
\end{tabular}

nutrient concentrations recorded (Table 1), nutrient limitation of the phytoplankton population was not considered to be a problem, thus we did not add nutrients to the incubation medium. Incubations were conducted in situ over $24 \mathrm{~h}$, at $0.5 \mathrm{~m}$ below the surface. Chlorophyll concentration was estimated by spectrophotometry (Lorenzen 1967) from water samples filtered on Whatman GF/C glass-fiber filters.

Determination of parameters. The grazing rate of microzooplankton on chlorophyll and growth rates of chlorophyll were calculated assuming the exponential growth model of Landry \& Hassett (1982):

$$
P_{t}=P_{0} \mathrm{e}^{(k-g) t}
$$

where $P_{0}$ and $P_{t}$ represent chlorophyll concentrations at the beginning and the end of an experiment, $k$ represents the algal growth coefficient and $g$ is the coefficient of algal mortality due to grazing. The coefficients $k$ and $g$ were determined by least-squares linear regression analysis between the 'apparent' growth rate $(k-g)$ of chlorophyll and the fraction of the undiluted sea water in each bottle. Using values of $k$ and $g$ together with the initial chlorophyll concentration $\left(P_{0}\right)$, we calculated the following parameters according to Paranjape (1987) and Gifford (1988):

Actual chlorophyll production $\left(P_{\mathrm{a}}\right)=\left(P_{0} \times \mathrm{e}^{(k-g)}\right)-P_{0}$ Potential chlorophyll production $\left(P_{\mathrm{p}}\right)=\left(P_{0} \times \mathrm{e}^{k}\right)-P_{0}$ Calculated chlorophyll $\left(C_{c t}\right)=\left(P_{0} \times e^{(k-g)}\right)$

Grazed chlorophyll $\left(G_{\mathrm{ch}}\right)=\left(P_{0} \times \mathrm{e}^{k}\right)-\left(P_{0} \times \mathrm{e}^{(k-g)}\right)$

Potential chlorophyll production grazed $(\%)$ $=100\left(P_{p}-P_{a}\right) / P_{p}$

Initial standing stock of chlorophyll grazed $(\%)$ $=100\left(P_{\mathrm{p}}-P_{\mathrm{a}}\right) /\left(P_{\mathrm{p}}+P_{0}\right)$

Taking into account the chlorophyll distribution versus salinity recorded the day after the experiments, the rate of chlorophyll change in situ was also calculated:

Rate of chlorophyll change in situ $(r r)=\ln \left(P_{1 \mathrm{n}} / P_{0}\right)$

Where $P_{1 n}$ is the in situ chlorophyll concentration corresponding to the water masses used in the grazing experiment 
Table 2. Microzooplankton grazing (g), phytoplankton growth $(k)$ and apparent phytoplankton growth rates $(d)$ obtained. from regressions. $n$ : number of samples; $\mathrm{r}^{2}$ : correlation coefficient. Significance levels: $p<0.05, \cdots p<0.01, \cdots p<0.001$ $M$ : waters of salinity higher than $31 ; \mathrm{A}$ : waters of salinity between 25 and 31 ; G: waters of salinity lower than 25 ; S: surface samples; F: bottom samples

\begin{tabular}{|c|c|c|c|c|c|c|}
\hline Sample & Salinity & $g\left(\mathrm{~d}^{-1}\right)$ & $k\left(d^{-1}\right)$ & $d\left(\mathrm{~d}^{-1}\right)$ & $r^{2}$ & $\mathrm{n}$ \\
\hline MS (8-9) & 31.4 & 1.34 & 2.76 & 1.43 & $0.795^{\circ}$ & 7 \\
\hline $\operatorname{AF}(8-9)$ & 30.3 & 1.17 & 3.08 & 1.91 & $0.781 " \cdot$ & 7 \\
\hline $\operatorname{AS}(8-9)$ & 27.1 & 0.94 & 2.97 & 2.04 & $0.902 \cdots$ & 7 \\
\hline $\mathrm{AF}(8-9)$ & 26.6 & 0.65 & 2.61 & 1.97 & $0.769^{\cdots}$ & 7 \\
\hline GS $(8-9)$ & 14.1 & 0.65 & 1.77 & 1.13 & $0.701^{\circ}$ & 6 \\
\hline GF (8-9) & 20.3 & 0.60 & 1.82 & 1.22 & $0.783^{\circ}$ & 7 \\
\hline $\operatorname{MS}(11-12)$ & 32.4 & 0.45 & 1.69 & 1.24 & 0.481 & 7 \\
\hline $\operatorname{MF}(11-12)$ & 33.8 & 0.56 & 1.42 & 0.86 & $0.574^{\circ}$ & 7 \\
\hline $\mathrm{AF}(11-12)$ & 30.3 & 0.84 & 1.87 & 1.02 & $0.905^{\cdots} \cdots$ & 7 \\
\hline GS $(11-12)$ & 21.9 & 0.17 & 1.48 & 1.31 & 0.358 & 7 \\
\hline GF (11-12) & 22.9 & 0.41 & 2.06 & 1.64 & 0.297 & 7 \\
\hline $\operatorname{MS}(14-15)$ & 32.8 & 0.42 & 1.21 & 0.79 & $0.958 \cdots$ & 7 \\
\hline$M F(14-15)$ & 33.4 & 0.18 & 1.48 & 1.30 & 0.085 & 7 \\
\hline AS $(14-15)$ & 29.6 & 0.59 & 1.41 & 0.82 & $0.788^{\circ}$ & 7 \\
\hline $\mathrm{AF}(14-15)$ & 30.8 & 0.63 & 1.81 & 1.19 & $0.874^{\cdots}$ & 7 \\
\hline GS $(14-15)$ & 14.2 & 0.63 & 1.27 & 0.65 & $0.736^{\circ}$ & 7 \\
\hline GF $(14-15)$ & 21.1 & 0.15 & 0.53 & 0.38 & 0.237 & 7 \\
\hline $\operatorname{MS}(17-18)$ & 33.6 & 0.67 & 2.21 & 1.55 & 0.408 & 7 \\
\hline AS $(17-18)$ & 27.8 & 0.52 & 0.92 & 0.39 & 0.472 & 7 \\
\hline $\operatorname{AF}(17-18)$ & 27.6 & 0.60 & 1.27 & 0.67 & $0.656^{\circ}$ & 7 \\
\hline GS $(17-18)$ & 14.6 & 1.22 & 2.31 & 1.09 & $0.624^{\circ}$ & 7 \\
\hline $\operatorname{MS}(20-21)$ & 33.7 & 2.22 & 3.41 & 1.19 & $0.844^{\prime \prime}$ & 7 \\
\hline $\operatorname{MF}(20-21)$ & 33.7 & 0.93 & 3.23 & 2.31 & $0.961 \cdots$ & 7 \\
\hline AS $(20-21)$ & 28.8 & 0.75 & 1.40 & 0.65 & 0.393 & 7 \\
\hline $\operatorname{AF}(20-21)$ & 28.9 & 0.74 & 1.10 & 0.36 & $0.932 \cdots$ & 7 \\
\hline GS $(20-21)$ & 18.3 & 0.96 & 2.19 & 1.23 & $0.928 \cdots$ & 7 \\
\hline GF $(20-21]$ & 24.3 & 0.11 & 1.18 & 1.07 & 0.351 & 7 \\
\hline $\operatorname{MS}(23-24)$ & 33.2 & 0.76 & 2.81 & 2.05 & $0.696^{\circ}$ & 7 \\
\hline $\operatorname{MF}(23-24)$ & 32.4 & 0.39 & 2.77 & 2.38 & 0.372 & 7 \\
\hline $\operatorname{AS}(23-24)$ & 29.5 & 0.61 & 1.50 & 0.89 & $0.823^{\circ}$ & 7 \\
\hline $\mathrm{AF}(2.3-24)$ & 29.0 & 1.50 & 2.13 & 0.63 & $0.824^{*}$ & 7 \\
\hline GS $(23-24)$ & 19.4 & 0.00 & 0.20 & 0.20 & 0.000 & 7 \\
\hline $\operatorname{MS}(26-27)$ & 34.6 & 1.33 & 2.02 & 0.69 & $0.639^{\circ}$ & 7 \\
\hline $\mathrm{MF}(26-27)$ & 34.1 & 2.09 & 3.17 & 1.08 & $0.828^{\circ}$ & 7 \\
\hline AS $(26-27)$ & 28.9 & 0.93 & 1.86 & 0.93 & $0.813^{\prime \prime}$ & 7 \\
\hline $\operatorname{AF}(26-27)$ & 28.9 & 0.74 & 1.39 & 0.65 & $0.766^{\circ}$ & 7 \\
\hline GS (26-27) & 22.4 & 0.81 & 2.18 & 1.38 & $0.773^{\circ}$ & 6 \\
\hline GF $(26-27)$ & 23.7 & 0.80 & 2.19 & 1.39 & $0.671^{\circ}$ & 7 \\
\hline
\end{tabular}

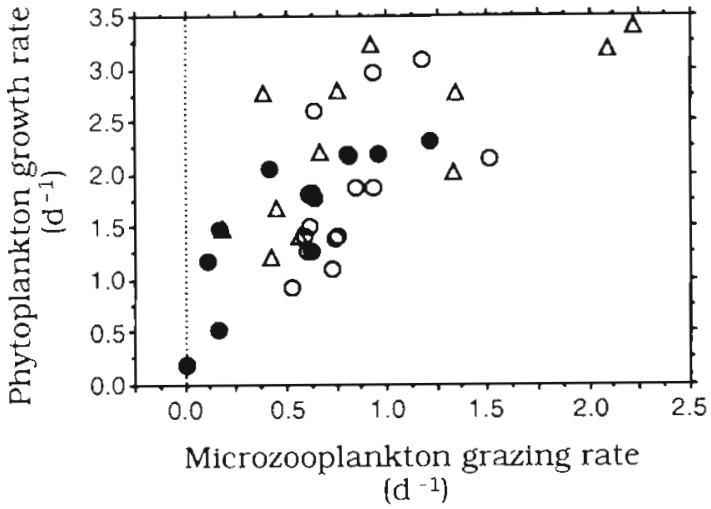

Fig. 3. Relationship between phytoplankton growth rates and microzooplankton grazing rates in zones with salinity of $<25(\bullet), 25$ to $31(0)$ and $>31(\Delta)$

\section{RESULTS}

Table 2 shows the phytoplankton growth rate, microzooplankton grazing rate, the apparent phytoplankton growth rate, and the correlation coefficient for each experiment. Most regressions were statistically significant and close to linearity. Maximum values of phytoplankton growth, apparent phytoplankton growth and grazing rates were $3.41,2.38$ and $2.22 \mathrm{~d}^{-1}$ respectively. The rate of chlorophyll change in situ reached a maximum value of $1.75 \mathrm{~d}^{-1}$.

Calculated parameters tended to increase with salinity (Table 3). Grazing rate varied from a mean value of $0.54 \mathrm{~d}^{-1}$ in the inner zone to $0.94 \mathrm{~d}^{-1}$ in the outer zone. Phytoplankton growth rates varied from 1.60 to $2.35 \mathrm{~d}^{-1}$ and apparent phytoplankton growth rates from mean values of about $1 \mathrm{~d}^{-1}$ in the 2 inner zones to $1.40 \mathrm{~d}^{-1}$ in the outer zone (Table 3). However, we only found statistically significant differences (ANOVA, p < 0.05 ) for growth rate between the outer and the inner zones (Tukey test, $\mathrm{p}<0.05$ ).

There were no statistically significant differences between values obtained from the surface and bottom

Table 3. Mean values and coefficient of variation of the calculated parameters for the 3 selected salinity ranges

\begin{tabular}{|lccc|}
\hline & $<25$ & $25-31$ & $>31$ \\
\hline Salinity & $19.8(18.8)$ & $28.9(4.3)$ & $33.2(2.6)$ \\
Grazing rate $\left(\mathrm{d}^{-1}\right)$ & $0.54(69.6)$ & $0.80(33.4)$ & $0.94(70.7)$ \\
Phytoplankton growth rate $\left(\mathrm{d}^{-1}\right)$ & $1.60(43.0)$ & $1.81(37.3)$ & $2.35(33.0)$ \\
Apparent phytoplankton growth rate $\left(\mathrm{d}^{-1}\right)$ & $1.06(40.8)$ & $1.01(56.2)$ & $1.40(40.7)$ \\
Rate of chlorophyll change in situ $\left(\mathrm{d}^{-1}\right)$ & $-0.16(251)$ & $0.08(637)$ & $0.29(261)$ \\
Initial standing stock of chlorophyll grazed $(\%)$ & $38.0(59.7)$ & $53.8(19.3)$ & $54.0(42.9)$ \\
Potential chlorophyll production grazed $(\%)$ & $46.5(52.2)$ & $66.9(14.2)$ & $60.6(37.1)$ \\
Initial chlorophyll concentration $\left(\mu g \mathrm{I}^{-1}\right)$ & $62.0(73.7)$ & $7.37(46.2)$ & $4.83(31.4)$ \\
In situ chlorophyll concentration $\left(\mu \mathrm{I}^{-1}\right)$ & $50.8(37.9)$ & $22.7(9.1)$ & $7.4)$ \\
Calculated chlorophyll concentration $\left(\mu \mathrm{g} \mathrm{I}^{-1}\right)$ & $162(39.1)$ & $30.4(105)$ & $23.8(82.5)$ \\
Grazed chlorophyll concentration $\left(\mu \mathrm{Ig}^{-1}\right)$ & $141.91 .2)$ & & $41.0(90.9)$ \\
\hline
\end{tabular}


samples for any of the 3 parameters calculated (grazing, phytoplankton growth and apparent phytoplankton growth) ( $p>0.05$, Student $t$-test), for the entire data set or for each of the considered salinity ranges.

Phytoplankton growth rate and microzooplankton grazing rate were correlated, but showed, at higher values, an asymptotic trend (Fig. 3). Correlations were significant for the entire data set $(p<0.01)$, and for the 3 salinity ranges, although the significance level decreased in the intermediate and outer salinity ranges $(\mathrm{p}<0.05)$.

Initial chlorophyll, calculated chlorophyll and in situ chlorophyll showed the same tendency: a decrease in value when salinity increased (Fig. 4). The differences in initial, calculated and in situ chlorophyll between the inner zone and the other 2 zones were statistically significant (ANOVA, $\mathrm{p}<0.05$; Tukey test, $\mathrm{p}<0.05$ ). For the total data set, correlation between calculated
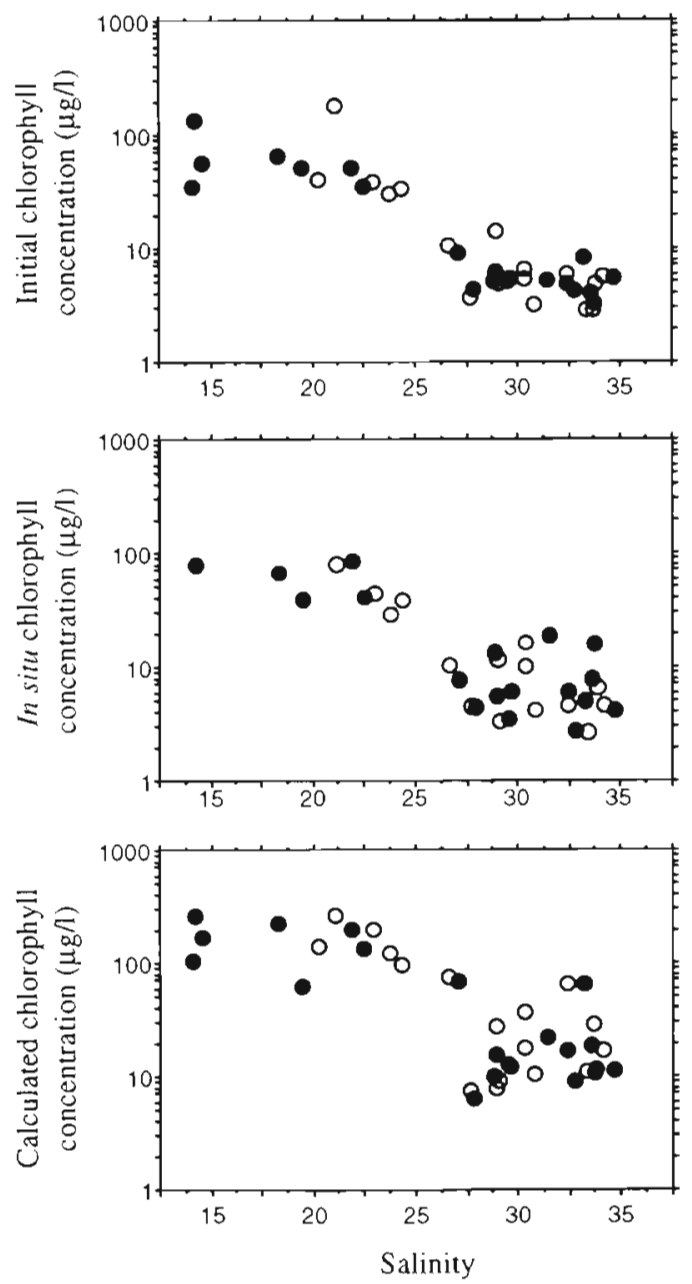

Fig. 4. The distribution of initial, in situ and calculated chlorophyll concentration in relation to salinity for surface samples (-) and bottom samples (O)
Table 4. Correlation coefticient between in situ and initial and calculated chlorophyll concentrations for the total data set and for the 3 salinity ranges considered. ' Statistically significant $(p<0.01)$

\begin{tabular}{|lcccc|}
\hline & \multicolumn{5}{c|}{ In situ chlorophyll } \\
& Tolal & $<25$ & $25-31$ & $>31$ \\
\hline Initial chlorophyll & $0.926 \cdots$ & $0.823 \cdots$ & 0.243 & -0.057 \\
Calculated chlorophyll & $0.865 \cdots$ & $0.727 \cdots$ & 0.150 & -0.274 \\
\hline
\end{tabular}

chlorophyll and in situ chlorophyll was significant (Table 4). The correlation between initial and in situ chlorophyll concentration was also significant. However, when we considered data by salinity ranges, correlations were significant only in the low salinity range, where phytoplankton biomass was higher.

The amount of chlorophyll grazed by the microzooplankton was higher in the low salinity range and minimal in the intermediate salinity range (Table 3 ). Maximum values of grazed chlorophyll accounted for $90 \%$ of the potential chlorophyll production and initial standing stock of chlorophyll (Fig. 5), but mean values constituted between 46 and $67 \%$ of the potential production and between 38 and $54 \%$ of the initial standing stock (Table 3). Losses were higher in the intermediate and outer zone and lower in the inner zone. Nevertheless, differences were only statistically sig-
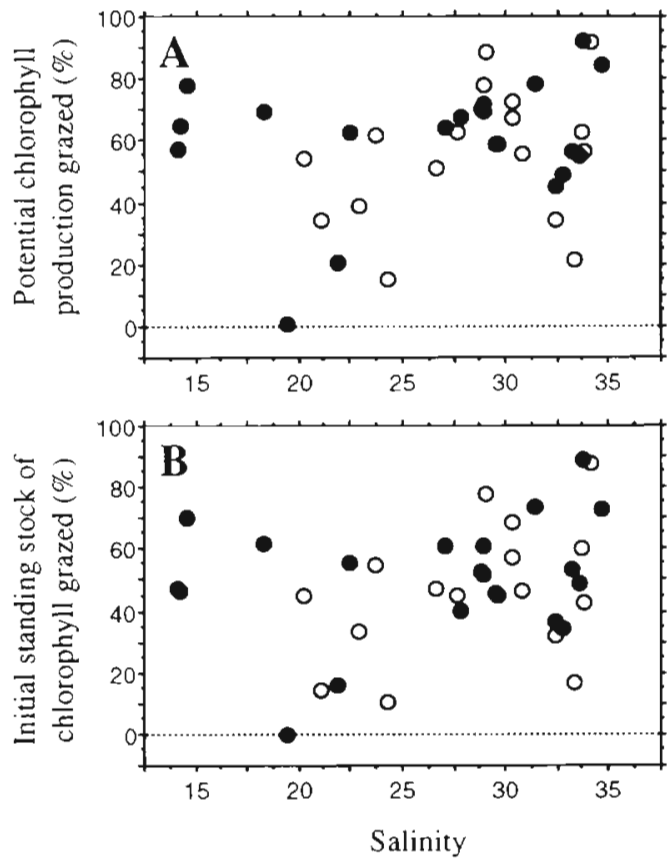

Fig. 5. The impact of grazing on phytoplankton in relation to salinity. (A) \% of potential primary production grazed and (B) $\%$ of initial standing stock grazed for surface samples ( and bottom samples (O) 
nificant for the potential chlorophyll production (ANOVA, $p<0.05$ ) due to differences between the values of the inner zone and the other 2 zones (Tukey test, $\mathrm{p}<0.05$ )

\section{DISCUSSION}

Our results confirm the general importance of microzooplankton grazing, which can remove more than $50 \%$ of chlorophyll production in this estuary. The mean values of algal growth and grazing rates obtained are similar to the highest values measured by Gallegos (1989) in a eutrophic estuary by means of the dilution method. Among studies carried out to estimate microzooplankton grazing using this method, the abovementioned study is likely the most suitable to compare with our results, because both studies were carried out in estuaries where chlorophyll concentrations were high. The high rates of algal growth and grazing found in our study area $\left(>2\right.$ to $\left.3 \mathrm{~d}^{-1}\right)$ could be due to the temperature registered in summer (usually higher than $23^{\circ} \mathrm{C}$ ), which favours their growth. Comparatively lower rates, usually below $1 \mathrm{~d}^{-1}$, have been obtained at lower temperatures, usually below $15^{\circ} \mathrm{C}$ (Strom \& Welschmeyer 1991, Verity et al. 1993). However, in a study carried out by McManus \& EderingtonCantrell (1992) in different seasons, the highest grazing and phytoplankton growth did not match with the highest temperatures. In consequence, other physicochemical or biological conditions could also influence these rates.

Taking into account the apparent growth, we obtained a mean rate of phytoplankton division between 2.3 and $3.4 \mathrm{~d}^{-1}$. These values are higher than those commonly reported in other studies (Furnas 1982, Alpine \& Cloern 1988), although cell division rates of up to 4 doublings per day have been reported in the literature (Fahnenstiel et al. 1995). Moreover, our data agree with those calculated by Franco (1994). By comparing chlorophyll concentrations between the morning and the evening, that author estimated a summer phytoplankton division rate of $3.0 \mathrm{~d}^{-1}$ at the outer zone and $1.2 \mathrm{~d}^{-1}$ at the intermediate zone. The carbon fixation rates per unit of chlorophyll estimated by Madariaga (1995) for this estuary also corroborate the very high phytoplankton growth obtained by chlorophyll balance methods.

The high grazing rates obtained could also suggest an over-estimation of values because the microzooplankton growth was not taken into account (Gallegos 1989), and a rapid growth of microzooplankton might be expected in the Estuary of Mundaka due to the high summer temperature. However, Landry et al. (1995) applied a new method to avoid the effect of the differ- ential microzooplankton growth in experimental bottles and found that grazing rates were similar to those estimated by the standard dilution method.

Algal growth and grazing rates were well correlated. This agrees with results given by other authors (e.g. Burkill 1987) who suggested the existence of a homeostatic mechanism in the microplankton assemblage expressed as a dynamic feedback coupling between zooplankton and phytoplankton. Grazing would maintain the phytoplankton population below the carrying capacity of the environment and in an exponential growth phase. In this situation, little energy is used for cellular maintenance and much more is transferred to consumers (Coffin \& Sharp 1987). The asymptotic trend observed for the relation between grazing and phytoplankton growth rates at the highest grazing rates indicates that the phytoplankton growth rates obtained were the highest possible.

Results from this study demonstrate that there were significant differences between both the rate of microzooplankton grazing and phytoplankton growth at different salinities. Both grazing and phytoplankton growth appeared to be highest in the outer part of the estuary and lowest in the inner part. A similar result was obtained by McManus \& Ederington-Cantrell (1992) for microzooplankton grazing in Chesapeake Bay (USA). With regard to phytoplankton, other studies corroborate that communities located in the outer estuary are more productive than those located in the inner estuary (Franco 1994, Madariaga 1995). Such differences could be the result of the change in the composition of the phytoplankton community along the salinity gradient. Although diatoms accounted for more than $50 \%$ of the phytoplankton biomass along the entire estuary, they are more important in the outer zone, where they reach $66 \%$ of phytoplankton biomass. In the intermediate and inner zones there is a higher relative proportion of dinoflagellates, green algae and cryptophyceans (Franco 1994).

Information on the abundance and composition of zooplankton smaller than $200 \mu \mathrm{m}$ is unfortunately restricted to the fraction between 20 and $200 \mu \mathrm{m}$ (Villate et al. 1993). According to this information, microzooplankton retained on the $20 \mu \mathrm{m}$ mesh (mainly larval stages of metazoans) is more abundant in the intermediate and high salinity ranges. However, our results showed that chlorophyll losses due to grazing were highest in the inner zone. This suggests that small protozoans passing through the $20 \mu \mathrm{m}$ mesh play a substantial role as phytoplankton grazers, at least in the inner estuary where copepods are absent. In fact, according to Christaki \& Van Wambeke (1995), the absence of copepod predation on protozooplankton promotes the grazing impact of microprotozoans on phytoplankton. Several studies have corroborated the 
importance of these small organisms in estuaries (e.g. Berk et al. 1987, Leakey et al. 1992). Sherr et al. (1991) demonstrated that protozoa present in estuaries actively eat phytoplankton, particularly algal cells between 2 and $6 \mu \mathrm{m}$. The fraction between 3 and $8 \mu \mathrm{m}$ is the most important fraction of phytoplankton biomass in the Estuary of Mundaka (Madariaga \& Orive 1989).

The differences in microzooplankton grazing rates observed between the outer and the inner estuary might be related to the differential distribution of zooplankton along the estuary due to salinity, eutrophic status or oxygen concentration (Dolan 1991, Sanders et al. 1992). The abovementioned change in phytoplankton community composition could also influence the rates of grazing because of phytoplankton selection by microzooplankton (McManus \& Ederington-Cantrell 1992).

The percentage of phytoplankton production removed by microzooplankton was found on occasions to represent near $100 \%$, although mean values were $\sim 50 \%$. Other works have also shown that microzooplankton grazing could consume a large percentage of phytoplankton production (Landry \& Hassett 1982, Welschmeyer \& Lorenzen 1985, Strom \& Welschmeyer 1991) and could control the growth of some species (Paranjape 1990).

In spite of the importance of microzooplankton grazing, the calculated values of chlorophyll were substantially higher than those measured in situ. Therefore, it can be supposed that in natural conditions there are other factors, like other grazers, export, etc., responsible for the in situ observed losses of chlorophyll concentration. Although mesozooplankton grazing impact is usually lower than $5 \%$ of the phytoplankton biomass (Ruiz 1995), benthic populations might also have a significant role in controlling phytoplankton stock in this estuary, since Iglesias and Navarro (1995) found that filter-feeder mollusks were able to filter $28 \%$ of the total water volume daily. On the other hand, the tidal prismivolume ratio in the Estuary of Mundaka is greater than 1 during spring tides (Villate et al. 1989). This phenomenon will affect phytoplankton population dilution and export in the outer zone, because the 'no return point' is located in waters with a salinity of 32. Waters with salinity above 32 are displaced beyond the estuary mouth during low tide, while waters with salinity below 32 are permanently inside the physical limits of the estuary (Ruiz 1995). In this zone, it is assumed that phytoplankton populations must compensate for these losses by means of high primary production. In fact, phytoplankton growth was found to be more important than initial chlorophyll concentration and microzooplankton grazing in the control of phytoplankton dynamics in the outer zone.
However, in the inner zone, initial phytoplankton biomass was relatively more important in the regulation of phytoplankton dynamics than algal growth and microzooplankton grazing. Because of this, a significant correlation was found between initial and in situ chlorophyll concentration. Hydrological stability might be important in the maintenance of phytoplankton biomass in this zone, where a water residence time of $7.5 \mathrm{~d}$ was estimated (Franco 1994).

In conclusion, microzooplankton grazing alone cannot explain the observed phytoplankton distribution along the salinity gradient.

Acknowledgements. Research was funded by University of Basque Country (Project UPV/EHU 118310-0078/89). A.R. and J.F. were supported by 2 grants from the Department of Education, Universities and Investigation of the Basque Government. We thank $\mathrm{H}$. Fraile for her technical assistance during field sampling. We also thank Astilleros de Murueta S.A. for the use of its facilities during surveys. I. Medrano corrected the English. Four anonymous reviewers provided helpful comments on the manuscript.

\section{LITERATURE CITED}

Alpine AE, Cloern JE (1988) Phytoplankton growth rates in a light-limited environment, San Francisco Bay. Mar Ecol Prog Ser 44:176-173

Berk SG, Brownlee DC, Heinle DR, Kling HJ, Colwell RR (1987) Ciliates as food source for marine planktonic copepods. Microb Ecol 4:27-40

Burkill PH, Mantoura RFC, Llewellyn CA, Owens NJP (1987) Microzooplankton grazing and selectivity of phytoplankton in coastal waters. Mar Biol 93:581-590

Castel $\mathbf{J}$ (1993) Long-term distribution of zooplankton in the Gironde Estuary and its relation with river flow and suspended matter. Cah Biol Mar 34:145-163

Christaki U, Van Wambeke F (1995) Simulated phytoplankton bloom input in top-down manipulated microcosms: comparative effect of zooflagellates, ciliates and copepods. Aquat Microb Ecol 9:137-147

Coffin RB, Sharp JH (1987) Microbial trophodynamics in the Delaware Estuary. Mar Ecol Prog Ser 41:253-266

Dolan JR (1991) Guilds of ciliate microzooplankton in the Chesapeake Bay. Estuar Coast Shelf Sci 33:137-152

Dolan JR, Gallegos CL (1991) Trophic coupling of rotifers, microflagellates, and bacteria during fall months in the Rhode River Estuary. Mar Ecol Prog Ser 77:147-156

Fahnenstiel GL, McCormick MJ, Lang GA, Redalje DG, Lohrenz SE, Markowitz M, Garrick HJ (1995) Taxon-specific growth and loss rates for dominant phytoplankton populations from the northern Gulf of Mexico. Mar Ecol Prog Ser 117:229-239

Franco J (1994) Variabilidad espacio-temporal de la biomasa y producción del fitoplancton en el Estuario de Urdaibai. Tesis doctoral, Facultad de Ciencias, UPV/EHU, Bilbao

Furnas MJ (1982) Growth rates of summer nanoplankton $(<10 \mu \mathrm{m})$ populations in lower Narragansett Bay, Rhode Island, USA. Mar Biol 70:105-115

Gallegos CL (1989) Microzooplankton grazing on phytoplankton in the Rhode River, Maryland: nonlinear feeding kinetics. Mar Ecol Prog Ser 57:23-33

Gifford DJ (1988) Impact of grazing by microzooplankton in 
the Northwest arm of Halifax Harbour, Nova Scotia. Mar Ecol Prog Ser 47:249-258

Hewes CD, Holm-Hansen O, Sakshaug E (1985) Alternate carbon pathways at lower trophic levels in the Antarctic food web. In: Siegfried WR, Condy PR, Laws RM (eds) Antarctic nutrient cycles and food webs. Springer-Verlag, Berlin, p 277-283

Iglesias IP, Navarro E (1995) Papel de los bivalvos en la Ría de Mundaka y análisis de los factores que afectan al crecimiento y reproducción de Cerastoderma edule. In: Angulo E, Quincoces I (eds) Reserva de la biosfera de Urdaibai. Investigación básica y aplicada. Gobierno Vasco, Vitoria, p 113-136

Kuuppo-Leinikki P (1990) Protozoan grazing on planktonic bacteria and its impact on bacterial population. Mar Ecol Prog Ser 63:227-238

Landry MR, Hassett RP (1982) Estimating the grazing impact of marine micro-zooplankton. Mar Biol 67:283-288

Landry MR, Kirshtein J, Constantinou J (1995) A refined dilution technique for measuring the community grazing impact of microzooplankton, with experimental tests in the central equatorial Pacific. Mar Ecol Prog Ser 120: $53-63$

Leakey RJG, Burkill PH, Sleigh MA (1992) Planktonic ciliates in Southampton water: abundance, biomass, production, and role in pelagic carbon flow. Mar Biol 114:67-83

Lorenzen CJ (1967) Determination of chlorophyll and pheopigments by spectrophotometric equations. Limnol Oceanogr 12:343-346

Madariaga I (1995) Photosynthetic characteristics of phytoplankton during the development of a summer bloom in the Urdaibai Estuary (Bay of Biscay). Estuar Coast Shelf Sci 40:559-575

Madariaga I, Orive E (1989) Spatio-temporal variations of size-fractionated primary production in the Gernika Estuary. J Exp Mar Biol Ecol 127:289-299

Madariaga I, Ruiz A (1989) Variabilidad a pequeña escala temporal de la concentración de nutrientes disueltos en el Estuario de Gernika (otoño e invierno). Kobie 17:49-56

Marra J, Wiebe PH, Bishop JKB, Stepien JC (1987) Primary production and grazing in the plankton of the Panama Bight. Bull Mar Sci 40:255-270

McManus GB, Ederington-Cantrell MC (1992) Phytoplankton pigments and growth rates, and microzooplankton grazing in a large temperate estuary. Mar Ecol Prog Ser 87:77-85

Muller H, Geller W (1993) Maximum growth rates of aquatic ciliated protozoa: the dependence of the body size and temperature reconsidered. Arch Hydrobiol 126:315-327

Paranjape MA (1987) Grazing by microzooplankton in the eastern Canadian arctic in summer 1983. Mar Ecol Prog

Editorial responsibility: Fereidoun Rassoulzadegan

Villefranche-sur-Mer, France
Ser 40:239-246

Paranjape MA (1990) Microzooplankton herbivory on the Grand Bank (Newfoundland, Canada): a seasonal study. Mar Biol 107:321-328

Peitsch A (1993) Difficulties in estimating mortality rates of Eurytemora affinis in the brackish water region of the Elbe Estuary. Cah Biol Mar 34:215-224

Rivier A, Brownlee DC, Sheldon RW, Rassoulzadegan F (1985) Growth of microzooplankton: a comparative study of bactivorous zooflagellates and ciliates. Mar Microb Food Webs 1:51-60

Ruiz A (1995) Aproximación al estudio de las interacciones tróficas en el plancton del Estuario de Urdaibai: caracterización del alimento y herbivorismo del zooplancton. Tesis doctoral, Facultad de Ciencias, UPV/EHU, Bilbao

Sanders RW, Caron DA, Berninger UG (1992) Relationships between bacteria and heterotrophic nanoplankton in marine and fresh waters: an inter-ecosystem comparison. Mar Ecol Prog Ser 86:1-14

Sherr EB, Sherr BF, McDaniel J (1991) Clearance rates of $<6 \mu \mathrm{m}$ fluorescently labeled algae (FLA) by estuarine protozoa: potential grazing impact of flagellates and ciliates. Mar Ecol Prog Ser 69:81-92

Smetacek V (1981) The annual cycle of protozooplankton in the Kiel Bight. Mar Biol 63:1-11

Strom SL, Welschmeyer NA (1991) Pigment-specific rates of phytoplankton growth and microzooplankton grazing in the open subarctic Pacific Ocean. Limnol Oceanogr 36: $50-63$

Tsuda A, Furuya K, Nemoto $T$ (1989) Feeding of micro- and macrozooplankton at the subsurface chlorophyll maximum in the subtropical North Pacific. J Exp Mar Biol Ecol 132:41-52

Verity PG, Stoecker DK, Sieracki ME, Nelson JR (1993) Grazing, growth and mortality of microzooplankton during the 1989 North Atlantic spring bloom at $47^{\circ} \mathrm{N}, 18^{\circ} \mathrm{W}$. Deep Sea Res I 40:1793-1814

Villate $F$ (1.991) Zooplankton assemblages in the shallow tidal Estuary of Mundaka (Bay of Biscay). Cah Biol Mar 32: $105-1.19$

Villate F, Franco J, Ruiz A, Orive E (1989) Caracterización geomorfológica e hidrológica de cinco sistemas estuáricos del País Vasco. Kobie 18:157-170

Villate F, Ruiz A, Franco J (1993) Summer zonation and development of zooplankton populations within a shallow mesotidal system: the Estuary of Mundaka. Cah Biol Mar 34:131-143

Welschmeyer NA, Lorenzen CJ (1985) Role of herbivory in controlling phytoplankton abundance: annual pigment budget for a temperate marine fjord. Mar Biol. 90:75-86

Submitted: April 9, 1997; Accepted: November 22, 1997

Proofs received from author(s): March 2, 1998 